DOI: $10.28925 / 2312-5829.2021 .310$

УДК: 37.032:51

\title{
ОЛЬГА ПОЛЕВІКОВА
}

Херсонський державний університет,

м. Херсон, Україна

polevikov@list.ru, ORCID iD 0000-0002-8144-1806

\section{ТЕТЯНА ШВЕЦЬ}

Херсонський державний університет,

м. Херсон, Україна,

tattishvets@gmail.com, ORCID iD 0000-0002-1234-0710

\section{ОСОБЛИВОСТІ ЛОГІКО-МАТЕМАТИЧНОГО РОЗВИТКУ ДОШКІЛЬНИКІВ ЗА ДОПОМОГОЮ ФЛЕШ-ІГОР}

У статті здійснено аналіз проблеми логіко-математичного розвитку старших дошкільників засобами флеш-ігор. Обтрунтована значимість математичної освіти відповідно до нових освітніх реалій: потреби імплементації Конщепиії розвитку природничо-математичної освіти (STЕМ-освіти) та нової Кониепиії розвитку дошкільної освіти.

Оскільки нині математика разом із інформатикою стає міждисииплінарним інструментарієм, а сучасні діти вільно почувають себе у світі інформаційних технологій, автори статті зазначають, що використання мережевих ресурсів дочільно спрямувати на користь освітнього процесу та забезпечення його якості. Одним із варіантів такого мережевого ресурсу є флеш-ігри - ігрові інтерактивні платформи, що забезпечують оптимізацію ігрового прочесу з метою розв'язання освітніх завдань.

Схарактеризовано специффіку дослідно-експериментальної роботи, щь обіймала два напрями. У першому - освітньому - виокремлено I етап пропедевтичний (критерії: абстрагування з показниками - вміння виокремлювати найбільш значущі характеристики об'єкта та вилучати несуттєві ознаки, де використовувалася флеш-гра; аналіз із показниками - вміння визначати взаємозв'язок предмета й об'єктів; зіставляти й аналізувати отримані дані; синтез із показниками - вміння дотримуватися законів логіки, будувати гіпотези $i$ з'ясовувати наслідки міркувань;); II етап - реалізаційний (критерії: класифікація з показниками - вміння виконувати логічні операції, свідомо їх аргументувати, формулювати підстави для класифікації об 'єктів; серіація з показниками - вміння розкладати набір елементів у відповідності до встановлених між ними зв'язків; II напрям - консультаиійний: робота з педагогічним колективом та з батьками вихованців.

Результативність здійсненої роботи виявлено за допомогою n'яти діагностичних методик, ретельно описаних у статті. 
Ключові слова: діагностичні методики, діти дошкільного віку, логікоматематичний розвиток, математична освіта, флеш-ігри.

(C) Полєвікова Ольга, Швець Тетяна, 2021

Вступ. Актуальність розвитку математичної освіти дошкільників обгрунтована сучасними викликами, де на тлі глобальних проблем, зокрема, епідеміологічних, відбувається значне зростання технічного прогресу, проникнення математичних методів та математичного стиля мислення у різні галузі науки. Сучасна математика разом із інформатикою стає міждисциплінарним інструментарієм, котрий забезпечує виконання важливих функцій: по-перше, освітньої, що дає змогу навчати фахівця-професіонала цілеутворенню та визначенню умов і можливих ризиків у досягненні мети; по-друге, аналітичної, тобто опрацювання на моделях можливих ситуацій й отримання оптимальних рішень. Математичні методи використовують не лише у техніці, механіці, електроніці, економіці, але й у медицині, екології, психології, соціології, лінгвістиці, історії, юриспруденції тощо через їх чіткість, універсальність, поєднання індукції та дедукції, точність кількісних характеристик. Також математика забезпечує формування й розуміння наукової картини світу, сприяє розвитку уяви, навичок раціонального мислення та способів вираження думки. Таким чином, нині математичні знання вкрай необхідні для успішного й комфортного буття людини.

Значимість математичної освіти обгрунтована у Концепції розвитку природничо-математичної освіти (STEM-освіти) (5 серпня 2020 р.), що базується, зокрема, на основних положеннях програмного документа «Дослідження STEMкомпетентностей для XXI століття», який було прийнято Міжнародним бюро 3 питань освіти ЮНЕСКО у лютому 2019 року. У Концепції розвитку дошкільної освіти, імплементація якої запланована МОН України з 2021 року, проголошено компетентнісний підхід, принцип навчання через гру.

У зв'язку із цим логіко-математичний розвиток дошкільників слід розглядати в контексті ігрової діяльності. Оскільки сучасні діти активно користуються 
гаджетами, вільно почувають себе в світі сучасних інформаційних технологій, варто цифровізацію обернути на користь освітнього процесу.

Мета статті - здійснити аналіз проблеми логіко-математичного розвитку старших дошкільників засобами флеш-ігор.

Теоретичне обгрунтування проблеми. Вікові межі процесу формування логічних умінь досліджували Ж.Піаже, А.Валлон, В.Рубцов та ін. У працях Л. Виготського, П. Гальперіна, А. Усової доведено, що дошкільники спроможні розуміти наукові поняття відповідно до віку. Наукові розвідки Л.Венгера, О.Запорожця дозволили вченим виявити суттєві зв’язки, доступні дітям у процесі предметно-чуттєвої діяльності. А.Столяр розроблено ідею логічної підготовки дошкільників під час серії авторських дидактичних ігор. З.Михайлова запропонувала ігри з блоками 3.Дьєнеша та паличками Дж.Кюїзенера.

У тлумаченні термінів «логіко-математичний розвиток» і «логіко-математична компетентність» спираються на визначення Н.Баглаєвої, Л.Зайцевої, Н.Непомнящої, К.Щербакової та ін.

Під логіко-математичним розвитком дітей дошкільного віку вчені розуміють позитивні зрушення у пізнавальній сфері особистості, що є результатом засвоєння математичних уявлень та пов’язаних із ними логічних операцій.

Науковцями доведено, що математика посідає значне місце в інтелектуальному розвитку дітей, рівень якого визначається на підставі сформованості у дошкільників логіко-математичних уявлень та понять (абстрагування, аналіз, синтез, причинно-наслідкові зв’язки, класифікація, серіація). Отже, зміст освіти має бути зорієнтовано на створення бази ключових логікоматематичних уявлень у дітей, основних понять і забезпечення умов для засвоєння дошкільниками вмінь аналізувати, міркувати, узагальнювати, робити висновки.

Інтерес до математики успішно формується у дошкільників через гру (Б.Нікітін, З.Михайлова, Р.Непомняща, А.Столяр).

Такі вчені як Feliks Gorski, Alex Soares, Adelheid Reinhardt, David Nascimento, Gabriella Domeny, Mozilla Firefox, Peer Dorow, Benjamin Cooper, Zsuzsanna Csarnai Straub обгрунтували вплив флеш-ігор на дітей дошкільного віку. 
Флеш-гра - це ігрова інтерактивна платформа, що забезпечує оптимізацію ігрового процесу з метою розв'язання освітніх завдань.

Методологія та методи дослідження. Дослідження було спрямовано на 3'ясування впливу флеш-ігор на логіко-математичний розвиток здобувачів дошкільної освіти. Відповідно до цього нами було організовано спеціальну роботу, яка обіймала два напрями.

У першому - освітньому - ми виокремили такі етапи: I етап пропедевтичний (критерії: абстрагування з показниками - вміння виокремлювати найбільш значущі характеристики об’єкта та вилучати несуттєві ознаки; флеш-гра: «Обери транспорт»; аналіз із показниками - вміння визначати взаємозв'язок предмета й об’єктів; зіставляти й аналізувати отримані дані; флеш-гра: «Чиї сліди?»; синтез із показниками - вміння дотримуватися законів логіки, будувати гіпотези і з'ясовувати наслідки міркувань; флеш-гра: «Коли це буває?»); II етап реалізаційний (критерії: класифікація з показниками - вміння виконувати логічні операції, свідомо їх аргументувати, формулювати підстави для класифікації об’єктів; флеш-ігри «Художник помилився», «Знайди пару»; серіація з показниками - вміння розкладати набір елементів у відповідності до встановлених між ними зв’язків; флеш-ігри: «Знайди пару», «Логічні зв’язки», «У пошуках тіні», «До лісу по гриби», «Пограймо в сніжки», «Чий голос чути на фермі?»); II напрям консультаційний: робота 3 педагогічним колективом та з батьками вихованців.

В експерименті взяли участь 44 здобувачі дошкільної освіти, 6 вихователів та 22 представники батьків.

На констатувальному та контрольному етапах педагогічного експерименту відповідно до зазначених вище критеріїв та показників нами було використано п’ять діагностичних методик. Схарактеризуємо їх.

Перша методика «Виокремлення суттєвих ознак» була спрямована на визначення у дошкільників здатності виокремлювати найбільш значущі характеристики об'єкта та вилучати несуттєві ознаки.

Обладнання: 20 карток із наборами слів, ручки. 
Процедура обстеження. Дитині пропонували 3 набору слів виокремити найбільш значущі характеристики об'єкта та вилучити ознаки, несуттєві для нього. Наприклад, квадрат (сторони, креслення, кути, червоний, рівний).

Оцінювання. Високий рівень (3 бали) - дитина самостійно виконує 18-20 завдань; середній рівень (2 бали) - 16-17 завдань; низький рівень - 0-13 завдань.

Друга методика «Порівняння понять» дозволила виявити вміння визначати зв'язки між предметами й об’єктами, аналізувати їх.

Процедура обстеження. Дитині пропонували порівняти 20 понять (наприклад, море - озеро), вказати на схожість і різницю, проаналізувати їх.

Оцінювання. Високий рівень (3 бали) - дитина самостійно виконує 18-20 завдань; середній рівень (2 бали) - 15-17 завдань; низький рівень - 0-14 завдань.

Третя методика «Схема оцінювання логічних прийомів мислення» сприяла виявленню вміння дотримуватися дітьми законів логіки, знаходити на цій основі закономірності й тенденції розвитку, будувати гіпотези й прогнозувати наслідки.

Обладнання: картки з картинками, картки з видовою відмінністю предметів.

Хід обстеження. Дитині пропонувалося уважно розглянути картинки i відповісти на питання: «Чи є відмінності у карток?». Якщо дитина вибирала тільки ознаку порівняння як назви предметів, зображених на картках, ії запитували: «Як ти думаєш, чи однакова кількість фруктів кошику? Як ти думаєш, що потрібно зробити, щоб їх стало порівну?»

Оцінювання виконання завдання. Високий рівень (3 бали) - дитина самостійно виокремлює підставу для порівняння, ознаки подібності, відмінності; присутність мовленнєвих формулювань ознак подібності та відмінності. Середній рівень (2 бали) - дитина за допомогою дорослого виділяе ознаки подібності, порівняння за допомогою дорослого промовляє формулювання ознаки подібності та відмінності. Низький рівень (1 бал) - дитина не справляється із завданням навіть за допомогою дорослих, не відповідає на запитання.

Четверта методика «Об'єднай у групи» дозволила з'ясувати, чи вміє дитина свідомо здійснювати логічні операції, аргументувати їх вибір та формулювати підставу для класифікації об'єктів. 
Обладнання: серія картинок, на яких представлені різні предмети, що супроводжуються спеціальною інструкцією.

Процедура виконання. Дитині пропонувалося уважно розглянути картинку й об’єднати представлені на ній фігури у якомога більшу кількість груп. До кожної такої групи мають належати фігури, що виділяються за спільною для них ознакою. Слід назвати всі фігури, що входять в кожну з виділених груп, і ту ознаку, за якою вони виділені. На виконання всього завдання відводилося 3 хвилини.

Оцінювання виконання завдання. Високий рівень (3 бали) - дитина самостійно правильно виконала завдання за 1,5 хвилини і менше. Середній рівень (2 бали) дитина правильно виконала завдання за 1,5 - 2,5 хв. Низький рівень (1 бал) - дитина за 3 хвилини не впоралася із завданням або допускала помилки.

П’ята методика «Пошук закономірностей» була спрямована на виявлення вміння дітей розташовувати набір елементів у відповідності 3 наявним між ними зв'язком.

Обладнання: малюнки із завданнями.

Процедура виконання. Респонденту пропонувалося назвати, хто буде перебувати наступним у кожному ряду запропонованих картинок.

Оцінювання виконання завдання. Високий рівень (3 бали) - дитина всі чотири завдання виконала самостійно і правильно. Середній рівень (2 бали) - виконано лише 2-3 завдання із чотирьох. Низький рівень (1 бал) - дитина виконала правильно лише 1 завдання.

Результати та дискусії. Прикінцевий етап дослідження засвідчив, що кількість дітей старшого дошкільного віку в експериментальній групі (далі - ЕГ) за показниками високого рівня логіко-математичного розвитку значно вища за кількість дітей цього рівня в контрольній групі (далі - КГ). Що стосується низького рівня, то кількість дітей в ЕК, яка перебувала на цьому рівні, значно менша, ніж в КГ.

Так, порівняльний аналіз досліджуваного вміння виокремлювати найбільш значущі характеристики об’єкта та вилучати несуттєві ознаки (перша методика «Виокремлення суттєвих ознак») у старших дошкільників ЕГ та КГ засвідчила, що в 
ЕГ дітей із високим рівнем більше (35\%), ніж у КГ (13\%); середній рівень розвитку мали на контрольному етапі $60 \%$ респондентів ЕК та $63 \%$ КГ. Дітей із низьким рівнем уміння виокремлювати найбільш значущі характеристики об'єкта та вилучати несуттєві ознаки в ЕГ менше (5\%), ніж у КГ (24\%).

Використання флеш-ігор в освітньому процесі старших дошкільників позитивно вплинуло на вміння дітей визначати зв'язки між предметами й об'єктами та аналізувати їх (друга методика «Порівняння понять»). Після обробки отриманих даних на контрольному етапі експерименту було виявлено майже в чотири рази більше дітей високого рівня досліджуваного явища в ЕГ (41\%), ніж у КГ (11\%). Середній рівень засвідчили 59\% в ЕГ та 64\% в КГ. Діти 3 низьким рівнем уміння визначати зв'язки між предметами й об'єктами та аналізувати їх в ЕГ відсутні, у КГ $-25 \%$.

Порівняльний аналіз сформованості вміння дотримуватися дітьми законів логіки, знаходити на цій основі закономірності й тенденції розвитку, будувати гіпотези й прогнозувати наслідки (третя методика «Схема оцінювання логічних прийомів мислення») на контрольному етапі засвідчив, що здобувачів дошкільної освіти з високим рівнем в ЕГ більше у п'ять разів (51\%), ніж у КГ (10\%).

Низький рівень уміння дотримуватися дітьми законів логіки, знаходити на цій основі закономірності й тенденції розвитку, будувати гіпотези й прогнозувати наслідки на контрольному етапі в ЕГ виявлено у 14\% респондентів, у КГ - у $31 \%$.

Стосовно вміння свідомо здійснювати логічні операції, аргументувати їх вибір та формулювати підставу для класифікації об’єктів (четверта методика «Об’єднай у групи») на контрольному етапі експерименту було виявлено 64\% дітей із високим рівнем досліджуваного явища в ЕГ та $10 \%$ у КГ; середній рівень засвідчили $25 \%$ респондентів ЕГ та 59\% КГ; низький рівень $11 \%$ ЕГ та $31 \%$ КГ.

Дітей із показниками високого рівня стосовно вміння розташовувати набір елементів у відповідності з наявним між ними зв'язком (п'ята методика «Пошук закономірностей») в ЕГ значно більше (39\%), ніж у КГ (18\%). Дітей із низьким рівнем в ЕГ $15 \%$, у КГ - $24 \%$. 
Отже, загальний рівень базових показників логіко-математичного розвитку дітей за всіма показниками у старших дошкільників ЕГ значно вищий, ніж у здобувачів дошкільної освіти КГ, що засвідчує ефективність експериментальної роботи й підтверджує висновки зарубіжних учених.

Так, Feliks Gorski за допомогою власноруч розроблених флеш-ігор розвивав у дітей старшого дошкільного віку конструктивні здібності і просторове мислення, гнучкість розуму, логіко-математичне мислення. Учений зазначав, що сучасні технології навчання, засновані на флеш-грі, викликають інтерес фахівців дошкільної галузі через освітній потенціал таких ігор (Gorski Feliks, 2015, p.928).

Серед особливостей флеш-ігор варто зазначити можливість розроблення стратегій, перевірку гіпотез, творче розв'язання проблем і прийняття рішень, високий рівень розвитку мислення.

У флеш-іграх у зв'язку із розвитком технологій HTML-5, що спрямовані на поліпшення сумісності із сучасними браузерами, такими як Google Chrome, Mozilla Firefox пропонує використовувати мову JavaScript та його бібліотеку Pixi Js, використання якої дозволяє отримати доступ до інтерфейсу WinGL з відеокартою для рендера динамічних, графічних додатків в оточенні Інтернету.

Adelheid Reinhardt стверджує, що флеш-гра дозволяє спільно використовувати загальний досвід як основу для більш детального обговорення - це мікросвіт, де дошкільники розвивають базові логіко-математичні навички аналізу, синтезу, порівняння, класифікації, серіації. Діти висувають гіпотези, знаходять або ії докази, або спростовують дані припущення, аргументуючи їx (Reinhardt Adelheid, 2016, p.123).

David Nascimento стверджує, що флеш-гра може сприяти логікоматематичному розвитку дітей, а також високому рівню мислення, високій самооцінці. Завдяки яскравому сюжету, звуковому супроводу поліпшується здатність дітей аналізувати, зіставляти предмети, виділяючи їх істотні ознаки, або виключаючи зайві предмети, що характерно для базових показників логікоматематичного розвитку старших дошкільників (Nascimento David, 2016). 
Gabriella Domeny підкреслює, що результативність використання флеш-ігор у логіко-математичному розвитку і розвитку внутрішньої мотивації забезпечується через фантазію, контроль, виклик, цікавість і конкуренцію (Domeny Gabriella, 2014).

Peer Dorow пояснює, що застосування флеш-ігор $\epsilon$ ефективним із трьох причин: завдяки 1) ігровому контексту, 2) інтерактивному навчанню та 3) можливості об'єднання перших двох пунктів в один (Dorow Peer, 2016, p.15-16).

Zsuzsanna Csarnai Straub говорить про те, що флеш-гра дає змогу учаснику виконувати більше ролей: у якості інструктора для надання допомоги дитині і в якості координатора для полегшення освітнього процесу. Створюється сприятливе освітнє середовище, де дошкільники можуть працювати самостійно або 3 наставником (Zsuzsanna Csarnai Straub, 2016, p.34).

Benjamin Cooper виокремлював величезний потенціал флеш-ігор для мотивації i максимального залучення дітей через можливість взаємодіяти 3 іншими учасниками освітнього процесу, можливість грати і в закладі дошкільної освіти, і поза ним (Cooper Benjamin, 2016, p.20).

Висновки. Таким чином, порушена у статті проблема логіко-математичного розвитку дітей старшого дошкільного віку засобами флеш-ігор $є$ актуальною і вимагає подальшого теоретичного осмислення.

Адаптований та апробований пакет із 10 флеш-ігор на кожен критерій i показник сприяв логіко-математичному розвитку здобувачів дошкільної освіти, що підтверджують результати дослідно-експериментальної роботи. У значній мірі високі показники дітей ЕГ були досягнуті завдяки організованій взаємодії закладу дошкільної освіти та батьків вихованців.

Перспективи подальших досліджень убачаємо у з'ясуванні взаємозв'язку між внутрішньою мотивацією та рівнем активності дітей у флеш-грі.

\section{Література}

Бонч-Бруєвич Г. Ф. Технічні засоби навчання 3 використанням інформаційних комп'ютерних технологій : навч. посіб. Київ : КМПУ імені Б. Д. Грінченка, 2007. 44 c. 
Варзар Т. М. Дистанційна освіта в сучасній освітній діяльності. Украӥнознавство.2005. № 1. С. 116-119.

Горбань O.В. Освітній потенціал відеоігор: світоглядно-методологічні засади. URL: http://elibrary.kubg.edu.ua/id/eprint/28035/1/O Horban OPVSMZ OD 20193 4\%2826-27\%29.pdf

Дичківська І. М. Інноваційні педагогічні технології. К. Видавничий дім «Слово». 2013. $448 \mathrm{c}$.

Козлітін Д. О. Матющенко І. І. Медіа середовище сучасного дошкільника та роль майбутнього педагога у ньому. URL: http://elibrary.kubg.edu.ua/19452/6/Kozlitin_Matushenko_MVCH_3_2_2017.pdf

Кошель А. П. Використання здоров'язбережувальних технологій у дошкільному закладі URL: file:///D:/Downloads/VchdpuP_2016_135_12.pd f (дата звернення 20.09. 2018).

Крутій К. Готовність в умовах невизначеності. Методичні акценти в організації освітнього процесу в новому навчальному році. Дошкільне виховання. 2020. № 8. C. 3-9.

Мардарова І. Сучасні інформаційні технології як засіб організації пізнавальної діяльності дітей дошкільного віку. URL: http://www.nbuv.gov.ua/portal/Soc_Gum/Gnvp/2010_4_SV2/19.pdf

Мардарова I. Інформатизація дошкільної освіти : проблеми та перспективи розвитку. Науковий вісник Південноукраӥнського національного педагогічного університету імені К.Д. Ушинського. №5(112). 2016. С. 78-82.

Мисик О.С. Методологічні аспекти формування фахової компетентності в майбутніх вихователів дітей дошкільного віку. Педагогічний альманах. 2018. № 38 . C. $119-126$.

Пасічніченко А. В., Ковалевська Н. В. Психологічна характеристика соціальної тривожності дітей дошкільного віку. Дошкільна освіта у сучасному соиіокультурному просторі. Полтава, 2017. Вип. 1. С. 124-129.

Полєвікова О.Б., Швець Т.А. Безпечний світ дошкільника: метод. посіб. Харків. 2019. $143 \mathrm{c}$.

Полєвікова О.Б., Швець Т.А. Організація пошуково-дослідницької діяльності в дошкіллі : метод. посіб. Харків. 2018. 109 с.

Полєвікова О.Б., Швець Т.А. Сім'я та дитячий садок: виховуємо дитину разом : метод. посіб. Харків. 2018. 126 с.

Половіна О. А., Ліпчевська І. Л. Актуальні проблеми перспективності змісту сучасної дошкільної освіти. Молодий вчений. 2018. № 8.1. С. 89-93.

Шпак I. O. Сучасні педагогічні технологіï.URL: www.archive.nbuv.gov.ua/ Pfto/2009_4/files/ ped904_77.pdf

Adelheid, Reinhardt. (2016). The logic in flash games. Math journal for teachers and educators. Boston. C. 123-139.

Anderson, A., \& Anderson, J. (2018). Math-in-context: The types of math preschoolers 'do' at home. In I. Elia, J. Mulligan, A. Anderson, A. Baccaglini-Frank, \& C. Benz (Eds.), Contemporary research and perspectives on early childhood mathematics education. C. 183-202. 
Andersson, K., \& Gullberg, A. (2012). What is science in preschool and what do teachers have to know to empower children? Cultural Studies of Science Education, 9(2), 275-296. DOI:10.1007/s11422-012-9439-6.

Benjamin Cooper. (2016). Flash games in education. Modern technical science and their development. Boston, $18-26 \mathrm{pp}$.

Bustamante, A. S., White, L. J., \& Greenfield, D. B. (2018). Approaches to learning and science education in Head Start: Examining bidirectionality. Early Childhood Research Quarterly, 44, 34-42pp. DOI:10.1016/j.ecresq.2018.02.013.

Campbell, C., Speldewinde, C., Howitt, C., \& MacDonald, A. (2018). STEM practice in the early years. Creative Education,9(1), 11-25. DOI:10.4236/ce.2018.91002.

Carlsen, M., Erfjord, I., \& Hundeland, P. S. (Eds.). (2020). Mathematics education in the early years. Results from the POEM4 conference, 2018. Berlin.

Clemens, Kolb., Flash games for kids. Modern technical science and their development. Boston, 2016. 10-16pp.

David Nascimento. (2016). Software technology for the development of logical thinking of children. Modern technical science and their development. Boston. 20-26pp.

Feliks Gorski. (2015). Logical and mathematical study of the effect of the flash games on older preschoolers. Developmental psychology. № 6. 928-936pp.

Fridberg, M., Thulin, S., \& Redfors, A. (2018). Preschool children's collaborative science learning scaffolded by tablets. Research in Science Education, 48(5), 1007-1026pp. DOI:10.1007/s11165-016-9596-9.

Gabriella Domeny. (2014). Flash games at the present stage. The development of mathematics on the modern stage. California, 123-139pp.

Gomes, J., \& Fleer, M. (2019). The development of a scientific motive: how preschool science and home play reciprocally contribute to science learning. Research in Science Education, 49(2), 613-634. DOI:10.1007/s11165-017-9631-5.

Peer Dorow. (2016). Flash games and their technology. Modern technical science and their development. Madrid, 15-19pp.

Zsuzsanna Csarnai. (2016). Straumodern forms and methods of work for the development of logical thinking of children. Modern technical science and their development. Boston, 34-36pp.

\section{References}

Adelheid, Reinhardt (2016). The logic in flash games. Math journal for teachers and educators. Boston. 123-39 (in English).

Anderson, A., \& Anderson, J. (2018). Math-in-context: The types of math preschoolers 'do' at home. In I. Elia, J. Mulligan, A. Anderson, A. Baccaglini-Frank, \& C. Benz (Eds.), Contemporary research and perspectives on early childhood mathematics education. 183-202 (in English).

Andersson, K., \& Gullberg, A. (2012). What is science in preschool and what do teachers have to know to empower children? Cultural Studies of Science Education, 9(2), 275-296. DOI:10.1007/s11422-012-9439-6 (in English).

Benjamin Cooper. (2016). Flash games in education. Modern technical science and their development. Boston, 18-26 (in English). 
Bonch-Bruyevy`ch, G. F. (2007). Texnichni zasoby` navchannya z vy`kory`stannyam informacijny`x komp'yuterny`x texnologij : navch. posib. [Technical means of learning with the use of computer information technology]. Ky'yiv : KMPU imeni B. D. Grinchenka. 44 (in Ukrainian).

Bustamante, A. S., White, L. J., \& Greenfield, D. B. (2018). Approaches to learning and science education in Head Start: Examining bidirectionality. Early Childhood Research Quarterly, 44, 34-42. DOI:10.1016/j.ecresq.2018.02.013 (in English).

Campbell, C., Speldewinde, C., Howitt, C., \& MacDonald, A. (2018). STEM practice in the early years. Creative Education,9(1), 11-25. DOI:10.4236/ce.2018.91002 (in English).

Carlsen, M., Erfjord, I., \& Hundeland, P. S. (Eds.). (2020). Mathematics education in the early years. Results from the POEM4 conference, 2018. Berlin (in English).

Clemens Kolb, (2016) Flash games for kids. Modern technical science and their development. Boston,. 10-16 (in English).

David Nascimento, (2016). Software technology for the development of logical thinking of children. Modern technical science and their development. Boston. 20-26 (in English).

Dy`chkivs`ka, I. M. (2013). Innovacijni pedagogichni texnologiyi. [Innovative pedagogical technologies]. K. Vy`davny`chy`j dim «Slovo». 448 (in Ukrainian).

Feliks Gorski. (2015). Logical and mathematical study of the effect of the flash games on older preschoolers. Developmental psychology. № 6. 928-936 (in English).

Fridberg, M., Thulin, S., \& Redfors, A. (2018). Preschool children's collaborative science learning scaffolded by tablets. Research in Science Education, 48(5), 1007-1026. https://doi.org/10.1007/s11165-016-9596-9 (in English).

Gabriella Domeny. (2014). Flash games at the present stage. The development of mathematics on the modern stage. California, 123-139 (in English).

Gomes, J., \& Fleer, M. (2019). The development of a scientific motive: how preschool science and home play reciprocally contribute to science learning. Research in Science Education, 49(2), 613-634. https://doi.org/10.1007/s11165-017-9631-5 (in English).

Gorban`, O.V. (2019). Osvitnij potencial videoigor: svitoglyadno-metodologichni zasady'.[Educational potential of video games: worldview and methodological principles].URL:http://elibrary.kubg.edu.ua/id/eprint/28035/1/O_Horban_OPVSMZ_ OD_2019_3-4\%2826-27\%29.pdf (in Ukrainian).

Koshel`, A. P. (2016). Vy`kory`stannya zdorov'yazberezhuval'ny`x texnologij u doshkil nomu zakladi. [Use of health technologies in preschool]. URL: file:///D:/Downloads/VchdpuP_2016_135_12.pd f (data zvernennya 20.09. 2018) (in Ukrainian).

Kozlitin, D. O. ,Matyushhenko, I. I. (2017). Media seredovy`shhe suchasnogo doshkil`ny`ka ta rol` majbutn`ogo pedagoga u n`omu. [The media environment of the modern preschooler and the role of the future teacher in it].URL: http://elibrary.kubg.edu.ua/19452/6/Kozlitin Matushenko MVCh 3 2 2017.pdf (in Ukrainian). 
Krutij, K. (2020). Gotovnist` v umovax nevy`znachenosti. Metody`chni akcenty` v organizaciyi osvitn`ogo procesu $\mathrm{v}$ novomu navchal`nomu roci. [Readiness in conditions of uncertainty. Methodical accents in the organization of the educational process in the new school year].Doshkil ne vy`xovannya. № 8. 3-9 (in Ukrainian).

Mardarova, I. (2010). Suchasni informacijni texnologiyi yak zasib organizaciyi piznaval`noyi diyal’nosti ditej doshkil`nogo viku. [Modern information technologies as a means of organizing the cognitive activity of preschool children].URL:http://www.nbuv.gov.ua/portal/Soc_Gum/Gnvp/2010_4_SV2/19.pdf (in Ukrainian).

Mardarova, I. (2016). Informaty`zaciya doshkil`noyi osvity` : problemy` ta perspekty`vy` rozvy`tku. [Informatization of preschool education: problems and prospects of development].Naukovy`j visny`k Pivdennoukrayins`kogo nacional’nogo pedagogichnogo universy`tetu imeni K.D.Ushy`ns`kogo. №5(112). 78-82 (in Ukrainian).

My`sy`k, O.S. (2018). Metodologichni aspekty` formuvannya faxovoyi kompetentnosti v majbutnix vy`xovateliv ditej doshkil`nogo viku. [Methodological aspects of formation of professional competence in future educators of preschool children]. Pedagogichny`j al ‘manax. 2018. № 38. 119-126 (in Ukrainian).

Pasichnichenko, A. V., Kovalevs`ka, N. V. (2017). Psy`xologichna xaraktery`sty`ka social`noyi try`vozhnosti ditej doshkil`nogo viku. [Psychological characteristics of social anxiety in preschool children]. Doshkil'na osvita u suchasnomu sociokul turnomu prostori. Poltava. Vy`p. 1. 124-129 (in Ukrainian).

Peer Dorow. (2016). Flash games and their technology. Modern technical science and their development. Madrid, 15-19.

Polovina, O. A., Lipchevs`ka, I. L. (2018). Aktual`ni problemy` perspekty`vnosti zmistu suchasnoyi doshkil'noyi osvity`. [Current issues of prospects for the content of modern preschool education]. Molody`j vcheny`j. №8.1. 89-93 (in Ukrainian).

Polyevikova, O.B., Shvecz', T.A. (2018). Organizaciya poshukovo-doslidny`cz`koyi diyal'nosti $\mathrm{v}$ doshkilli : metod. posib. [Organization of research activities in preschool]. Xarkiv.109 (in Ukrainian).

Polyevikova, O.B., Shvecz`, T.A. (2018). Sim'ya ta dy`tyachy`j sadok: vy`xovuyemo dy`ty`nu razom : metod. posib. [Family and kindergarten: raising a child together].Xarkiv. 126 (in Ukrainian).

Polyevikova, O.B., Shvecz`, T.A. (2019). Bezpechny`j svit doshkil`ny`ka: metod. posib. [Safe world of a preschooler]. Xarkiv. 143 (in Ukrainian).

Shpak, I. O. (2009). Suchasni pedagogichni texnologiyi. [Modern pedagogical technologies]. URL: www.archive.nbuv.gov.ua/ Pfto/2009_4/files/ ped904_77.pdf (in Ukrainian).

Varzar, T. M. (2005). Dy`stancijna osvita v suchasnij osvitnij diyal`nosti. [Distance education in modern educational activities]. Ukrayinoznavstvo. №1. 116 - 119 (in Ukrainian).

Zsuzsanna Csarnai. (2016). Straumodern forms and methods of work for the development of logical thinking of children. Modern technical science and their development. Boston, 34-36. 


\section{ОЛЬГА ПОЛЕВИКОВА,}

Херсонский государственный университет, г.Херсон, Украина

polevikov@list.ru, ORCID iD 0000-0002-8144-1806

\section{ТАТЬЯНА ШВЕЦ,}

Херсонский государственный университет, г. Херсон, Украина

tattishvets@gmail.com, ORCID iD 0000-0002-1234-0710

\section{ОСОБЕННОСТИ ЛОГИКО-МАТЕМАТИЧЕСКОГО РАЗВИТИЯ ДОШКОЛЬНИКОВ С ПОМОЩЬЮ ФЛЭШ-ИГР}

В статье осущуествлен анализ проблемы логико-математического развития старших дошкольников средствами флэи-игр. Обоснована значимость математического образования в соответствии с новыми образовательными реалиями: потребности имплементацуии Концеепции развития естественноматематического образования (STEM-образования) и новой Концепцуии развития дошкольного образования.

Поскольку сейчас математика вместе с информатикой становится междисииплинарным инструментарием, а современные дети свободно чувствуют себя в мире информационных технологий, авторы статьи отмечают, что использование сетевых ресурсов целесообразно направить на пользу образовательного процесса и обеспечение его качества.Одним из вариантов такого сетевого ресурса являются флэи-игры - игровые интерактивные платформы, обеспечивающче оптимизациию игрового процесса с изелью решения образовательных задач.

Авторами осуществлен анализ взглядов на уместность использования флэиигр доикольниками таких зарубежных ученых как Feliks Gorski, Alex Soares, Adelheid Reinhardt, David Nascimento, Gabriella Domeny, Mozilla Firefox, Peer Dorow, Benjamin Cooper, Zsuzsanna Csarnai Straub.

Охарактеризована специцфика опытно-экспериментальной работы, предполагающей два направления.

В первом - образовательном - выделен I этап - пропедевтический (критерии: абстрагирование с показателями - умение выделять наиболее значимые характеристики объекта и исключать несущуественные признаки, где использовалась флэи-игра «Выбери транспорт»; анализ с показателями - умение определять взаимосвязь предмета и объектов; сопоставлять и анализировать полученные данные; флэи-игра: «Чьи следыр?»; синтез с показателями - умение соблюдать законы логики, строить гипотезы и выяснять последствия рассуждений; флэш-игра «Когда это бывает?»); II этап - реализационньй (критерии: классификация с показателями - умение выполнять логические операции, осознанно их аргументировать, формулировать основания для классификацуии объектов; флэи-игры «Художник ошибся», «Найди пару»; сериация c показателями - умение раскладывать набор элементов в соответствии с установленными между ними связями; флэи-игры: "Найди пару», «Логические связи», «В поисках тени», «В лес за грибами», "Давай поиграем в снежки», "Чей 
голос сльшино на ферме?»); II направление - консультациионное: работа с педагогическим коллективом и с родителями воспитанников.

Результативность осущуествленной работы выявлена с помощуью пяти диагностических методик, тщательно описанных в статье.

Ключевые слова: дети доикольного возраста, диагностические методики, логико-математическое развитие, математическое образование, флэи-игры.

\section{OLGA POLEVIKOVA,}

Kherson State University, Kherson, Ukraine

polevikov@list.ru, ORCID iD 0000-0002-8144-1806

\section{TETIANA SHVETS,}

Kherson State University, Kherson, Ukraine

tattishvets@gmail.com, ORCID iD 0000-0002-1234-0710

\section{FEATURES OF LOGICAL AND MATHEMATICAL DEVELOPMENT OF PRESCHOOLERS WITH THE HELP OF FLASH GAMES}

The article analyzes the problem of logical and mathematical development of senior preschoolers by means of flash games. The importance of mathematical education has been substantiated in accordance with the new educational realities: the needs of the implementation of the Concept for the development of natural and mathematical education (STEM education) and the new Concept for the development of preschool education.

Since now mathematics, together with computer science, is becoming an interdisciplinary toolkit, and modern children feel free in the world of information technology, the authors of the article note that it is advisable to use network resources to benefit the educational process and ensure its quality.

One of the options for such a network resource are flash games - game interactive platforms that optimize the game process in order to solve educational problems.

The authors analyzed the views on the appropriateness of the use of flash games by preschoolers from such foreign scientists as Feliks Gorski, Alex Soares, Adelheid Reinhardt, David Nascimento, Gabriella Domeny, Mozilla Firefox, Peer Dorow, Benjamin Cooper, Zsuzsanna Csarnai Straub.

The specificity of the experimental work, which involves two directions, is characterized.

In the first educational - stage I is highlighted - propedeutic (criteria: abstraction with indicators - the ability to highlight the most significant characteristics of the object and exclude insignificant signs, where the flash game "Choose transport" was used; analysis with indicators - the ability to determine the relationship of an object and objects; to compare and analyze the data obtained; flash game: "Whose traces?"; synthesis with indicators - the ability to observe the laws of logic, build hypotheses and find out the consequences of reasoning; flash game "When does this happen?"); Stage II implementation (criteria: classification with indicators - the ability to perform logical operations, deliberately argue them, formulate the grounds for classifying objects; flash games "The artist was mistaken", "Find a pair"; serialization with indicators - the ability 
to lay out a set of elements in accordance with the connections established between them; flash games: "Find a pair", "Logical connections", "In search of a shadow", "Into the forest for mushrooms", "Let's play snowballs", "Whose voice is heard on the farm?"); II direction - consulting: work with the teaching staff and with the parents of the pupils.

The effectiveness of the work carried out was revealed using five diagnostic methods, carefully described in the article.

Key words: diagnostic techniques, flash games, logical and mathematical development, mathematical education, preschool children.

Стаття надійшла до редакції 11.08.2021

Прийнято до друку 23.09 .2021 